\title{
Rootstock Affected In- and Poststorage Performance of Grafted Watermelon Seedlings at Low Temperature
}

\author{
Hans Spalholz and Chieri Kubota ${ }^{1}$
}

\begin{abstract}
AdDiTIONAL INDEX wORDs. Citrullus lanatus, controlled environment, cold storage, Cucurbita maxima $\times$ Cucurbita moschata, Cucurbitaceae, greenhouse, Lagenaria siceraria, vegetable grafting
\end{abstract}

SUMMARY. Low-temperature storage is a technique to hold seedlings for a short period of time to adjust the production schedule of young seedlings. Laborintensive grafting propagation can potentially benefit from the effective use of this technique to minimize peak labor inputs. Watermelon (Citrullus lanatus) seedlings are generally chilling sensitive and therefore difficult to store at low temperatures. However, the rootstocks used for watermelon grafting, interspecific squash (Cucurbita maxima $\times$ Cucurbita moschata) and bottle gourd (Lagenaria siceraria) are known to be chilling tolerant. To examine the influence of rootstocks on storability of watermelon seedlings, young seedlings of 'Tri-X-313' seedless watermelon grafted onto 'Strong Tosa' interspecific squash, 'Emphasis' bottle gourd, and 'Tri-X-313' watermelon as rootstock were placed for 2 or 4 weeks under $12{ }^{\circ} \mathrm{C}$ air temperature and $12 \mu \mathrm{mol} \cdot \mathrm{m}^{-2} \cdot \mathrm{s}^{-1}$ photosynthetic photon flux $(P P F)$. Nongrafted watermelon seedlings were also treated in these same conditions. In addition, nonstored (grafted and nongrafted) seedlings were prepared for comparison. Regardless of seedling type (nongrafted or grafted with different rootstocks), all seedlings stored for 2 weeks had lower dry weight, comparable or greater number of leaves and stem length, when compared with their respective nonstored control groups after 2 weeks in the greenhouse. Seedlings stored for 4 weeks had lower number of leaves and stem length after 2 weeks in the greenhouse, except for those grafted onto the interspecific squash rootstock. Nongrafted and grafted watermelon seedlings with the same watermelon cultivar as rootstock showed significantly lower leaf net photosynthetic rates after 2 weeks in the greenhouse after the 2 -week storage than those of nonstored control groups. In contrast, when grafted onto interspecific squash and bottle gourd rootstocks, seedlings showed comparable net photosynthetic rate to the control group. For all seedling types, $20 \%$ to $35 \%$ of seedlings died during 4 -week storage or poststorage in the greenhouse, whereas all seedlings survived for the 2 -week storage, except when grafted onto watermelon as rootstock. Therefore, chilling-tolerant rootstocks 'Strong Tosa' interspecific squash and 'Emphasis' bottle gourd improved storability of grafted 'Tri-X-313' watermelon seedlings but could not extend the storability beyond 2 weeks.

$\mathrm{V}$

egetable grafting is the process of combining two compatible seedlings (scion and rootstock) to comprise one new seedling. Grafting onto rootstocks resistant to soilborne diseases can reduce the disease incidence of scion and improve the yield. For this reason, vegetable

\footnotetext{
School of Plant Sciences, The University of Arizona, Tucson, AZ 85721-0036

This project was funded by USDA NIFA SCRI (award number 2011-51181-30963).

We would like to thank Syngenta Seeds for providing watermelon and rootstock seeds. We also acknowledge our colleagues at the University of Arizona, specifically Ricardo Hernández and Mark Kroggel for technical assistances, and Ursula Schuch and Michael Ottman for critical review of the manuscript.

${ }^{1}$ Corresponding author. E-mail: ckubota@e-mail. arizona.edu.
}

doi: 10.21273/HORTTECH03577-16 grafting has been used to overcome issues associated with intensive cultivation in Asia and Europe (Lee et al., 2010), and recently evaluated in the United States (Pullano, 2016). Other advantages of grafting onto superior rootstocks include abioticstress tolerance, such as tolerance to low temperature (Davis et al., 2008;
Ntatsi et al., 2014) or saline environments (Colla et al., 2010), overcoming nutrient deficiencies (Schwarz et al., 2013 ), and improving fruit quality (King et al., 2010).

Despite the benefits of vegetable grafting, this technology is currently underused by commercial vegetable growers in the United States. Current capacity of vegetable nurseries to supply grafted seedlings is insufficient to meet the large, narrow-window, seasonal demand required by growers at time of transplanting. Low-temperature storage of grafted seedlings is one strategy to augment labor-intensive grafted seedling production. Using low-temperature storage allows propagators to maintain a more stable labor input while allowing an earlier start to seedling production. Grafting new seedlings while others are stored allows propagators to amass larger quantities of grafted seedlings that will have emerged from storage at the same stage of growth. The technique of low-temperature storage has been successfully demonstrated using ornamental plugs (Heins et al., 1995) and vegetable seedlings including watermelon (Ding et al., 2011; Duan et al., 2014), muskmelon [Cucumis melo (Justus and Kubota, 2010)], eggplant [Solanum melongena (Kubota et al., 2002; Wang et al., 2009)], pepper [Capsicum annuum (Kwack and Chun, 2015)], and tomato [Solanum lycopersicum (Park and Fujiwara, 2009, 2015)]. However, some species are chilling sensitive, which results in deteriorating seedling quality during and after low-temperature storage. For chilling-sensitive plants, a higher storage temperature must be selected to avoid loss of seedlings. Crop species in the cucurbit family (Cucurbitaceae) are generally known to be chilling sensitive, which limits the storability. For example, Ding et al. (2011) and Duan et al. (2014) could store watermelon seedlings at $15{ }^{\circ} \mathrm{C}$ up to $6 \mathrm{~d}$,

\begin{tabular}{llll}
\hline $\begin{array}{l}\text { Units } \\
\text { To convert U.S. to SI, } \\
\text { multiply by }\end{array}$ & U.S. unit & SI unit & $\begin{array}{l}\text { To convert SI to U.S., } \\
\text { multiply by }\end{array}$ \\
\hline 0.3048 & $\mathrm{ft}$ & $\mathrm{m}$ & 3.2808 \\
3.7854 & $\mathrm{gal}$ & $\mathrm{L}$ & 0.2642 \\
2.54 & inch $(\mathrm{es})$ & $\mathrm{cm}$ & 0.3937 \\
28,350 & $\mathrm{oz}$ & $\mathrm{mg}$ & $3.5274 \times 10^{-5}$ \\
7.4892 & $\mathrm{oz} / \mathrm{gal}$ & $\mathrm{g} \cdot \mathrm{L}^{-1}$ & 0.1335 \\
1 & $\mathrm{ppm}$ & $\mathrm{mg} \cdot \mathrm{L}^{-1}$ & 1 \\
1 & $\mathrm{ppm}$ & $\mu \mathrm{L} \cdot \mathrm{L}^{-1}$ & 1 \\
$\left({ }^{\circ} \mathrm{F}-32\right) \div 1.8$ & ${ }^{\circ} \mathrm{F}$ & ${ }^{\circ} \mathrm{C}$ & $\left({ }^{\circ} \mathrm{C} \times 1.8\right)+32$ \\
& & &
\end{tabular}


whereas Park and Fujiwara (2015) stored tomato seedlings at $10{ }^{\circ} \mathrm{C}$ for $21 \mathrm{~d}$. Obviously, a longer duration of storage is desired to provide more flexibility in managing production.

Within the same family, sensitivities to low temperature vary for different species. We examined seedling response of 22 nightshade (Solanaceae) and cucurbit scions and rootstocks treated in low-temperature storage (Spalholz, 2013). The study determined that watermelon was highly chilling sensitive when compared with other cucurbit species. In the cucurbits, interspecific hybrid squash was the most chilling tolerant, followed by bottle gourd. These two species are used widely as rootstock to graft watermelon seedlings.

Acquisition of chilling tolerance by grafting chilling-susceptible scion onto chilling-tolerant rootstock is one of the widely practiced objectives for grafting cucurbit crops. For example, productivity of cucumber ( $\mathrm{Cucu}$ mis sativus) was improved when grafted onto figleaf gourd (Cucurbita ficifolia) under cooler soil conditions (Ahn et al., 1999). Petropoulos et al. (2012) examined three different rootstocks, including gourd (two forms of L. siceraria) and 'RS 841 Fl' interspecific hybrid squash, for two different watermelon cultivars Sugar Baby and Crimson Sweet, and showed that a specific combination of watermelon scion and rootstock performed better than other combinations under low postgrafting temperatures. Therefore, grafting onto chilling-tolerant rootstock can be expected to improve the storability of chilling-susceptible scions in lowtemperature storage. In fact, Justus and Kubota (2010) showed that storability of chilling-sensitive 'Olympic Gold' muskmelon was enhanced when grafted onto chilling-tolerant 'Tetsukabuto' interspecific squash rootstock. Another study reported by Ding et al. (2011) showed that 'Zaojia 84-24' watermelon seedlings grafted onto 'Zhuangshi' squash (C. moschata) rootstock retained higher chlorophyll and soluble sugar during storage and exhibited higher net photosynthetic rate during the poststorage recovery than nongrafted watermelon seedlings.

In the present study, we grafted chilling-sensitive watermelon onto two selected rootstocks of interspecific hybrid squash and bottle gourd that were previously shown as chilling tolerant as well as the same watermelon cultivar, and stored them for 2 or 4 weeks to observe low-temperature storage response.

\section{Materials and methods}

Plant materials. 'Tri-X-313' seedless watermelon seeds (Syngenta Seeds, Boise, ID) were sown into 98-cell trays filled with a mix of a commercial substrate (Sunshine Mix \#3; Sun Gro Horticulture, Bellevue, WA) and perlite (West, Chandler, AZ) at a ratio of $3: 1$. Seeded trays were placed in a growth chamber at $29^{\circ} \mathrm{C}$ for $48 \mathrm{~h}$ and then moved to the greenhouse. Seeding was done 11 and $16 \mathrm{~d}$ before grafting when used as scion and rootstock, respectively. Seedlings were subirrigated with water as needed and with nutrient solution consisting of the following nutrients (in milligrams per liter): 70 nitrogen [N (nitrate form)], $7 \mathrm{~N}$ (ammonium form), 21 phosphorus, 117 potassium, 85 calcium, 12 magnesium, 16 sulfur, as well as micronutrients on day 11 (scion) and day 15 (rootstock) after seeding. Another set of 'Tri-X-313' watermelon seeds were sown to prepare nongrafted seedlings using the same germination method described above. Nongrafted seedlings were sown $16 \mathrm{~d}$ before storage.

'Strong Tosa' interspecific hybrid squash rootstock seeds (Syngenta Seeds) were germinated on moist filter papers in petri dishes placed in a dark growth chamber at $29^{\circ} \mathrm{C}$. After $36 \mathrm{~h}$, germinated seeds were placed into 98-cell trays filled with the same substrate mix, covered with vermiculite, and moved to the greenhouse. Seeding was performed Il d before grafting. Seedlings were subirrigated with water as needed and once with the same nutrient solution before grafting.

'Emphasis' bottle gourd rootstock seeds (Syngenta Seeds) were sown into 98-cell trays filled with the same substrate mix. The seeds were then covered with a layer of vermiculite and then placed in a temperaturecontrolled chamber set at $29^{\circ} \mathrm{C}$. After $48 \mathrm{~h}$, the seeds were moved to the greenhouse. Seeding was performed $12 \mathrm{~d}$ before grafting. Seedlings were subirrigated with water as needed and once with the same nutrient solution before grafting.
In addition, each nonstored seedling seeding date was scheduled to correspond with the removal of seedlings from storage. The nonstored seedlings were to be at the same growth stage as the stored seedlings were at the start of storage. Nonstored seedlings (grafted and nongrafted) were grown using the same procedure as the stored seedlings from 2 and 4 weeks prior, respectively. All grafting was done on 29 Oct. 2012 for stored seedlings and 15 and 29 Nov. 2012 for nonstored seedlings to compare with 2 - and 4-week-stored seedlings, respectively. Removal of seedlings from 2 and 4 weeks of storage was on 24 Nov. and 8 Dec. 2012, respectively.

Greenhouse conditions. A greenhouse (Tucson, AZ) covered with rigid double-layer acrylic panels was used in this experiment. Padand-fan evaporative cooling system and overhead air heating system were used for ambient temperature control. In addition, a high-pressure fogging system was used for humidification with a minimum set point of $55 \%$ relative humidity. When moved to the greenhouse, the seedlings were placed on thermostatically controlled heating mats and covered with a plastic tent during the night to maintain a nighttime substrate temperature of $20^{\circ} \mathrm{C}$. Greenhouse air temperature and PPF were measured using an aspirated and radiationshielded sensor (CS500; Campbell Scientific, Logan, UT) placed at the center of the greenhouse and a quantum sensor (LI-190; LI-COR, Lincoln, NE) placed above the gutter height $(9 \mathrm{ft})$, respectively. The sensor readings were scanned every minute and averaged every $15 \mathrm{~min}$ to record in a data logger (CR-10; Campbell Scientific). Daytime $P P F$ was integrated to compute the daily light integral (400 to $700 \mathrm{~nm}$ ) assuming that the average $P P F$ was not changed over each 15 min recording interval. Average daytime and nighttime air temperatures and daily light integral inside the greenhouse during the experiment (13 Oct. 2012 to 17 Feb. 2013) were $21.7 \pm 1.3{ }^{\circ} \mathrm{C}$ (day), $15.4 \pm 0.67^{\circ} \mathrm{C}$ (night), and $20.1 \pm 4.13 \mathrm{~mol} \cdot \mathrm{m}^{-2} \cdot \mathrm{d}^{-1}$, respectively (Fig. 1).

GRAFTING AND HEALING conditions. Sixty-six seedlings were grafted for each combination of scion and rootstock, using the 

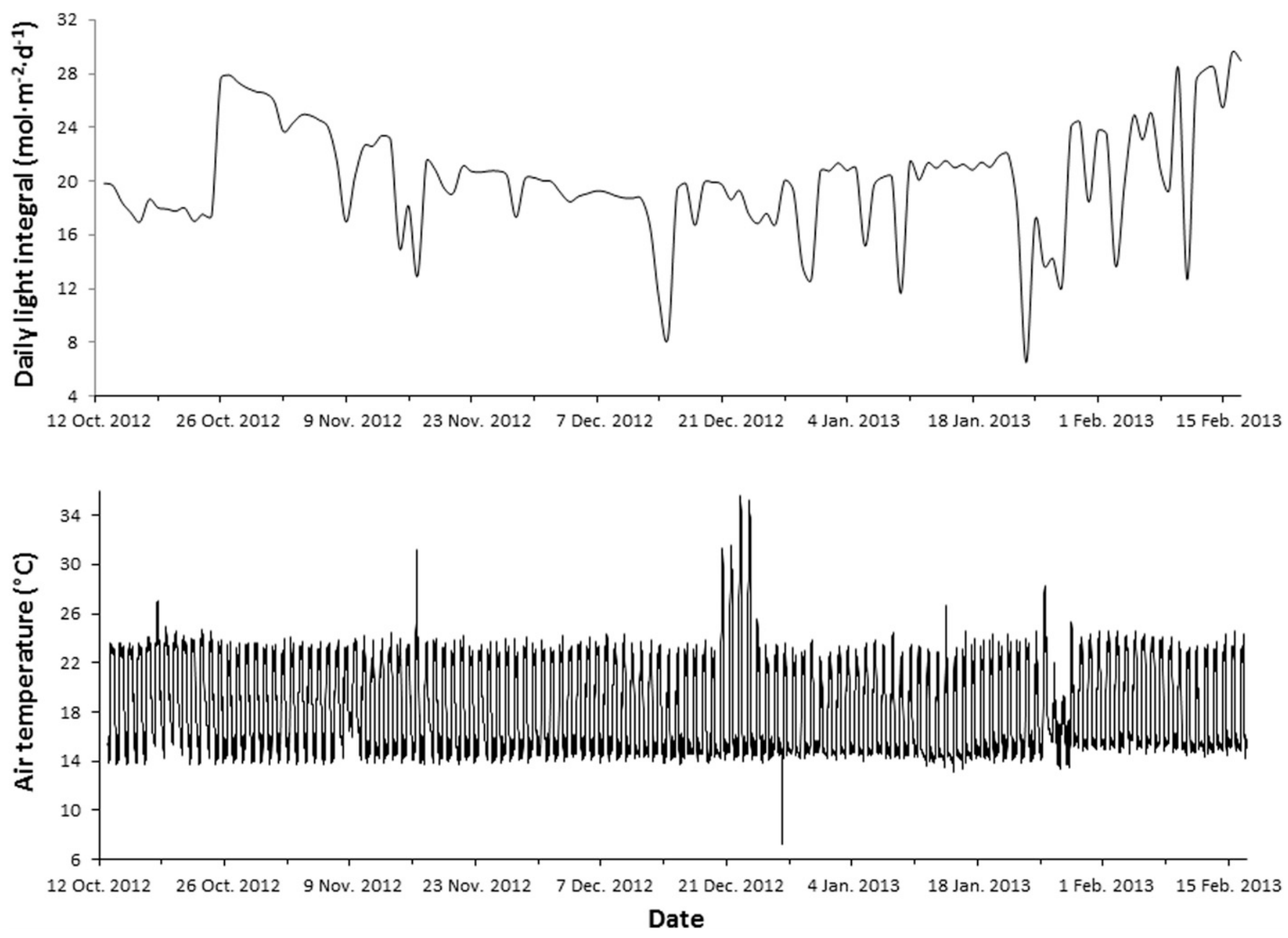

Fig. 1. Daily light integral and air temperature recorded in the greenhouse during the experiment (from 13 Oct. 2012 to 17 Feb. 2013); $\left({ }^{\circ} \mathrm{C} \times 1.8\right)+32={ }^{\circ} \mathrm{F}$.

single-cotyledon method as described by Hassell et al. (2008). The newly grafted seedlings were placed into clear 14-gal containers with about $1.5 \mathrm{~cm}$ of water at the bottom and covered by a single layer of polyethylene plastic film held down by elastic bands. Seedlings were sprayed with $0.52 \mathrm{~g} \cdot \mathrm{L}^{-1}$ myclobutanil (Rally 40WSP; Dow Agrosciences, Indianapolis, IN) and $0.04 \mathrm{~mL} \cdot \mathrm{L}^{-1}$ mefenoxam (Ridomil Gold; Syngenta, Basel, Switzerland) to prevent fungal infection before the healing boxes were sealed. Healing boxes were then placed in a temperature-controlled chamber for $7 \mathrm{~d}$. The first $24 \mathrm{~h}$ of healing were in complete darkness followed by the remainder of healing under continuous light at $65 \mu \mathrm{mol} \cdot \mathrm{m}^{-2} \cdot \mathrm{s}^{-1} P P F$, at a height of $40 \mathrm{~cm}$ from the bottom of the shelf. Cool-white fluorescent lamps (F40T12/CW PLUS/ALTO; Philips Lighting, Amsterdam, The Netherlands) were used as the light source. Air temperature inside the healing boxes was maintained at $29{ }^{\circ} \mathrm{C}$. Relative humidity was $100 \%$ in the healing boxes for $4 \mathrm{~d}$ and was then gradually reduced to ambient humidity conditions within the remaining $3 \mathrm{~d}$. At the end of the $7-\mathrm{d}$ healing period, the seedlings were moved to the greenhouse for acclimatization under $80 \%$ shadecloth on the first day and $50 \%$ on the second. Grafted seedlings were given $3 \mathrm{~d}$ of full sun after acclimatization before placement into storage. Irrigation with the same nutrient solution was applied during this period.

STORAge CONDitions. A total of 40 seedlings from each of the grafted and nongrafted groups were selected randomly from those prepared for 2- or 4-week storage. These seedlings were then placed into the same 14-gal containers $(20$ seedlings per container, two containers per each type of seedlings) and covered by a single layer of polyethylene plastic film. The top corners of the container were left free of polyethylene plastic to allow for ventilation to prevent container conditions from reaching $100 \% \mathrm{hu}^{-}$ midity. Seedlings were sprayed with myclobutanil and mefenoxam at the same rates as described earlier to prevent fungal infection before the boxes were placed into storage. After being sprayed, seedlings were placed into a walk-in cold room controlled at $12{ }^{\circ} \mathrm{C}$. Cool white fluorescent lamps were used as the light source, were positioned at a height about $75 \mathrm{~cm}$ from the shelf surface and delivered an average $P P F$ of $12 \mu \mathrm{mol} \cdot \mathrm{m}^{-2} \cdot \mathrm{s}^{-1}$. Seedlings were subirrigated with water as needed. Storage box temperature was monitored by using data loggers (Hobo Pro Series; Onset, Pocasset, MA).

Poststorage conditions. After the 2 - and 4-week storage treatments, 
seedlings were placed back in the greenhouse to observe and compare poststorage growth and development with nonstored control seedlings. Stored seedlings required a $2-\mathrm{d}$ poststorage acclimatization under $80 \%$ shadecloth on the first day and $50 \%$ on the second. One week after the final day of storage, all seedlings were transplanted into 3 -inch pots. The seedlings were subirrigated when necessary with the same nutrient solution as described earlier to maintain ample substrate moisture. Water was substituted for nutrient solution every third subirrigation to prevent the accumulation of salt.

P L A N T G R O W T H A N D PHOTOSYNTHESIS MEASUREMENTS AND OBSERVATION. Number of leaves (>1 cm leaf blade), stem length, and shoot dry weight were measured [ $\mathrm{n}=$ 20 , unless there was a loss due to chilling injury $(\mathrm{CI})]$ on day 0 (before storage), after 2 or 4 weeks in storage, and finally after 2 weeks in the greenhouse after storage. Fresh shoot samples were oven-dried at $80^{\circ} \mathrm{C}$ for $72 \mathrm{~h}$ in folded paper envelopes to obtain samples of dry weight.

Poststorage photosynthetic capacity was assessed using a portable photosynthesis system (Ciras-2; PP systems, Amesbury, MA) set at $400 \mu \mathrm{mol} \cdot \mathrm{mol}^{-1}$ carbon dioxide and $1000 \mu \mathrm{mol} \cdot \mathrm{m}^{-2} \cdot \mathrm{s}^{-1} \mathrm{PPF}$. Measurements were taken between 0800 and 1400 HR after 2 weeks in the greenhouse after 2 -week storage on leaves that developed during the poststorage phase. The youngest fully matured leaf of both stored and nonstored seedlings $(\mathrm{n}=8)$ were used for measurement. No measurements were taken on 4-week stored seedlings due to inadequate leaf size and loss of measurable leaves due to the CI.

A small number of seedlings $(\mathrm{n}=$ 4) from both stored and nonstored seedling groups were kept in the greenhouse to observe their flower development, to preliminary assess possible effects of storage on early flower development. Days to flower for both male and female flowers were recorded for each plant.

STATISTICAL ANALYSis AND EXPERIMENTAL DESIGN. All data were analyzed by $t$ test using JMP software (version 9.0; SAS Institute, Cary, NC). The experiment was conducted using a completely randomized design once between Oct. 2012 and Feb. 2013, with two storage containers for each scion-rootstock combination subject to 2 - or 4-week storage. There was no interaction between seedlings in these two containers and the data were therefore pooled $(\mathrm{n}=20$, unless otherwise specified).

\section{Results and discussion}

Plant survival in storage. All seedlings survived the 2 -week storage; however, $5 \%$ of seedlings grafted on watermelon died after $3 \mathrm{~d}$ in poststorage (data not shown). Watermelon seedlings were shown to be storable for $6 \mathrm{~d}$ at $15{ }^{\circ} \mathrm{C}$ in darkness (Ding et al., 2011). Grafting to squash rootstock (Ding et al., 2011) and illumination in storage (Duan et al., 2014) were shown to improve the in- and poststorage plant physiology and growth. The relatively short storage time (only $6 \mathrm{~d}$ ) used by these studies was likely due to the higher storage temperature $\left(15^{\circ} \mathrm{C}\right)$, compared with our study $\left(12^{\circ} \mathrm{C}\right)$. Table 1 shows the progress of plant mortality caused by 4 -week storage in our present experiment. Loss of seedlings due to CI was not evident up to 3 weeks in storage. However, $5 \%$ to $15 \%$ of seedlings were dead by end of storage and $10 \%$ to $35 \%$ of seedlings were lost after 2 weeks of poststorage.
Although majority of seedlings could survive the 4 -week storage, it is not recommended due to the high risk of losing seedlings.

POSTSTORAGE SHOOT DRY WEIGHT INCREASE, DEVELOPMENT, AND PHOTOSYNTHESIS. All seedlings stored for 2 weeks maintained the shoot fresh or dry weight at a similar level as prior to the storage and increased the shoot weight and number of leaves steadily with time after storage (data not shown). However, we found that nonstored grafted seedlings had $18 \%$ to $31 \%$ greater dry weight when compared after the 2 -week poststorage period, whereas number of leaves was similar to or fewer than those of stored seedlings of the corresponding type (Table 2). When grafted onto interspecific hybrid squash or bottle gourd, net photosynthetic rates of 2 -week stored seedlings were not significantly different from those of nonstored control seedlings, whereas net photosynthetic rates were reduced significantly for seedlings grafted onto watermelon or nongrafted seedlings. These observations suggest that the 2 -week storage reduced the growth of watermelon seedlings in storage but their photosynthetic capacity was recovered during the poststorage when grafted onto interspecific hybrid squash or bottle gourd. Ding et al. (2011) also found that leaf net photosynthetic rate of watermelon seedlings that were dark stored for $6 \mathrm{~d}$ at $15{ }^{\circ} \mathrm{C}$ was greater when grafted on squash rootstock.

Stem length was $10 \%$ to $21 \%$ greater for 2-week stored seedlings than nonstored seedlings, except the seedlings grafted onto interspecific hybrid squash rootstock. Stem extension during storage is not desirable, as compact plant architecture is often desired for transplants. More studies

Table 1. In- and poststorage mortality of grafted and nongrafted seedlings when stored for 4 weeks at $12{ }^{\circ} \mathrm{C}\left(53.6^{\circ} \mathrm{F}\right)$ and $12 \mu \mathrm{mol} \cdot \mathrm{m}^{-2} \cdot \mathrm{s}^{-1}$ photosynthetic photon flux. Watermelon seedlings were grafted onto interspecific squash (WM/IS), bottle gourd (WM/BG), watermelon (WM/WM), or not grafted.

\begin{tabular}{|c|c|c|c|c|c|c|c|c|}
\hline \multirow{2}{*}{$\begin{array}{l}\text { Plant type } \\
\text { (scion/rootstock) }\end{array}$} & \multicolumn{6}{|c|}{ Mortality in storage $(\%)^{\mathrm{z}}$} & \multicolumn{2}{|c|}{ Mortality poststorage (\%) } \\
\hline & Day 0 & Day 1 & Day 7 & Day 14 & Day 21 & Day 28 & Day 31 & Day 42 \\
\hline \multicolumn{9}{|l|}{ Grated seedlings } \\
\hline $\mathrm{WM} / \mathrm{IS}$ & 0 & 0 & 0 & 0 & 0 & 15 & 35 & 35 \\
\hline WM/BG & 0 & 0 & 0 & 0 & 0 & 5 & 25 & 30 \\
\hline WM/WM & 0 & 0 & 0 & 0 & 0 & 5 & 20 & 20 \\
\hline Nongrafted seedlings & 0 & 0 & 0 & 0 & 0 & 0 & 10 & 25 \\
\hline
\end{tabular}

$\mathrm{z}_{\mathrm{n}}=40$.

$\mathrm{y}_{\mathrm{n}}=20$. 
Table 2. Poststorage growth parameters and leaf net photosynthetic rate (NPR) of watermelon seedlings, as affected by 2 - or 4-week storage at $12{ }^{\circ} \mathrm{C}\left(53.6^{\circ} \mathrm{F}\right)$ and $12 \mu \mathrm{mol} \cdot \mathrm{m}^{-2} \cdot \mathrm{s}^{-1}$ photosynthetic photon flux when seedlings were grafted on interspecific squash (WM/IS), bottle gourd (WM/BG), watermelon (WM/WM) rootstock, or not grafted. Measurements were taken after 2 weeks of poststorage growth in the greenhouse.

\begin{tabular}{|c|c|c|c|c|c|c|c|}
\hline \multirow[b]{2}{*}{$\begin{array}{l}\text { Plant type } \\
\text { (scion/rootstock) }\end{array}$} & \multicolumn{4}{|c|}{ 2-week storage $(\text { mean } \pm S E)^{\mathrm{z}}$} & \multicolumn{3}{|c|}{ 4-week storage $(\text { mean } \pm S E)^{\mathrm{z}}$} \\
\hline & $\begin{array}{l}\text { Shoot dry wt } \\
\left(\mathrm{mg} / \text { plant }^{\mathrm{y}}\right.\end{array}$ & $\begin{array}{c}\text { Leaves } \\
\text { (no./plant) }\end{array}$ & $\begin{array}{c}\text { Stem } \\
\text { length }(\mathrm{cm})^{\mathrm{y}}\end{array}$ & $\begin{array}{c}\mathrm{NPR} \\
\left(\mu \mathrm{mol} \cdot \mathrm{m}^{-2} \cdot \mathrm{s}^{-1}\right)\end{array}$ & $\begin{array}{c}\text { Shoot dry } \\
\text { wt (mg/plant) }\end{array}$ & $\begin{array}{c}\text { Leaves } \\
\text { (no./plant) }\end{array}$ & $\begin{array}{c}\text { Stem } \\
\text { length }(\mathrm{cm})\end{array}$ \\
\hline WM/IS, stored & $514.6 \pm 28.3^{*}$ & $5.5 \pm 0.27^{\mathrm{Ns}}$ & $7.5 \pm 0.20^{\mathrm{Ns}}$ & $21.0 \pm 1.26^{\mathrm{Ns}}$ & $512.9 \pm 33.4^{*}$ & $5.7 \pm 0.21^{*}$ & $8.5 \pm 1.54^{\mathrm{Ns}}$ \\
\hline WM/IS, nonstored & $668.6 \pm 19.2$ & $5.0 \pm 0.17$ & $7.7 \pm 0.15$ & $23.4 \pm 0.56$ & $599.9 \pm 17.16$ & $5.1 \pm 0.14$ & $9.43 \pm 0.81$ \\
\hline $\mathrm{WM} / \mathrm{BG}$, stored & $443.4 \pm 19.7^{*}$ & $5.6 \pm 0.20^{\mathrm{Ns}}$ & $10.1 \pm 0.38^{*}$ & $21.4 \pm 1.04^{\mathrm{Ns}}$ & $302.6 \pm 19.2^{*}$ & $5.1 \pm 0.40^{*}$ & $10.0 \pm 1.85^{*}$ \\
\hline WM/WM, nonstored & $402.9 \pm 14.2$ & $5.0 \pm 0.14$ & $7.7 \pm 0.19$ & $22.6 \pm 1.12$ & $488.5 \pm 26.4$ & $6.2 \pm 0.17$ & $13.6 \pm 2.44$ \\
\hline $\begin{array}{l}\text { Nongrafted seedlings, } \\
\text { stored }\end{array}$ & $241.2 \pm 11.3^{*}$ & $4.0 \pm 0.07^{*}$ & $7.3 \pm 0.22^{*}$ & $16.4 \pm 1.68^{*}$ & $114.1 \pm 6.1^{*}$ & $3.4 \pm 0.17^{\mathrm{Ns}}$ & $5.3 \pm 0.69^{*}$ \\
\hline $\begin{array}{l}\text { Nongrafted seedlings, } \\
\text { nonstored }\end{array}$ & $342.2 \pm 11.8$ & $3.4 \pm 0.11$ & $6.0 \pm 0.13$ & $22.7 \pm 0.49$ & $283.3 \pm 11.4$ & $3.4 \pm 0.12$ & $6.8 \pm 0.85$ \\
\hline
\end{tabular}

need to be done to prevent stretching, including optimizing the light environment and water management during storage.

Four-week stored seedlings grafted on interspecific squash, bottle gourd, or watermelon had lower dry weight than the nonstored comparison group after 2 weeks of poststorage in the greenhouse. The reduction of dry weight was the smallest (15\%) when grafted onto interspecific squash. Number of leaves and stem length of stored seedlings were similar or greater than the corresponding nonstored group, when grafted on interspecific hybrid squash, but were significantly smaller when grafted on bottle gourd, watermelon as rootstock, or nongrafted (except the number of leaves for nongrafted seedlings). Although 4-week storage may not be practical at nurseries due to the risk of losing some plants as stated before, these differences in plant response between rootstocks indicate the impact of rootstock chilling tolerance on scion storability. CI is often associated with loss of water conductivity in roots, likely caused by the altered "gating" of root-specific aquaporins. For example, Lee et al. (2005a, 2005b) suggested that chilling-sensitive cucumber root aquaporins exhibited conformational changes that likely reduced water conductivity, more than chilling-tolerant figleaf gourd roots. Of interest, Ahamed et al. (2012) suggested a shoot to root signal was likely involved for inducing the expression of aquaporin genes in the root. Chilling stress also induces anatomical [e.g., endodermal suberization (Lee et al., 2005a)] and biochemical difference in roots [e.g., membrane fatty acid profile (Ko et al., 2006)] between sensitive and tolerant plants. In storage, root zone temperature is typically at a similar temperature as the air temperature. It would be interesting to examine possible influence of root-zone temperature control during low-temperature storage.

In the present experiment, light intensity $(P P F)$ during storage was selected based on our previous study of storing melon seedlings at the same temperature of $12{ }^{\circ} \mathrm{C}$ (Justus and Kubota, 2010). Earlier studies on low-temperature storage of vegetable seedlings showed that the optimum light intensity for storage was at the whole-plant light compensation point where plant net photosynthetic rate and therefore carbon balance equal null (e.g., Kubota et al., 2002). Light quality has been also known to affect the changes in seedling quality during storage (Kubota et al., 1996) and green light-emitting diodes were more effective to preserve plant quality (Park and Fujiwara, 2009, 2015). Further optimization of light intensity as well as light quality in storage may contribute to extending the storage time of grafted watermelon.

Flower Development. In the present experiment, only a small number of seedlings $(n=4)$ were kept in the greenhouse to observe flower development as affected by the storage duration and rootstock. Therefore, the results discussed here are considered preliminary. However, all plants developed first male and female flowers after 37 to $43 \mathrm{~d}$ and 40 to $44 \mathrm{~d}$ after 2 -week storage, respectively. There was no significant difference in days to flowering for both first male and female flowers between plants stored vs. nonstored at the seedling stage (data not shown). These findings are similar to what Justus and Kubota (2010) found in their study when observing flowering in muskmelon grafted onto 'Tetsukabuto' interspecific hybrid squash rootstock. When seedlings were stored for 4 weeks, however, rootstock affected the days to first male and female flowers. When grafted onto interspecific hybrid squash rootstock or bottle gourd, the days to flower was unaffected by the storage; whereas flowering was significantly delayed by 16 to $22 \mathrm{~d}$ when grafted onto watermelon as rootstock or were nongrafted (data not shown). This indicates the benefit of low-temperature-tolerant rootstocks when low-temperature storage is intended for chillingsensitive scions.

\section{Conclusion}

Our preliminary data of flower development, along with the plant growth, development, and leaf photosynthesis 
data from the 2-week storage experiment, suggests that 2 -week storage is feasible for grafted watermelon seedlings especially when grafted onto interspecific hybrid squash or bottle gourd rootstock. However, 4-week storage caused loss of seedlings regardless of rootstock. Further investigation is needed to determine optimal conditions for storage periods longer than 2 weeks to reduce seedling death and improve poststorage recovery.

\section{Literature cited}

Ahamed, A., M. Murai-Hatano, J. IshikawaSakurai, H. Hayashi, Y. Kawamura, and M. Uemura. 2012. Cold stress-induced acclimation in rice is mediated by rootspecific aquaporins. Plant Cell Physiol. 53:1445-1456.

Ahn, S., Y. Im, G. Chung, B. Cho, and S. Suh. 1999. Physiological responses of grafted-cucumber leaves and rootstock roots affected by low root temperature. Sci. Hort. 81:397-408.

Colla, G., Y. Rouphael, C. Leonardi, and Z. Bie. 2010. Role of grafting in vegetable crops grown under saline conditions. Sci. Hort. 127:147-155.

Davis, R., P. Perkins-Veazie, Y. Sakata, S. López-Galarza, M. Vicente, S. Lee, Y. Huh, Z. Sun, A. Miguel, S. King, R. Cohen, and J. Lee. 2008. Cucurbit grafting. Crit. Rev. Plant Sci. 27:50-74.

Ding, D., B. Bei, W. Jiang, Q. Duan, D. Hongmei, and D. Huang. 2011. Physiological advantages of grafted watermelon (Citrullus lanatus) seedlings under lowtemperature storage in darkness. HortScience 46:993-996.

Duan, Q., W. Jiang, M. Ding, Y. Lin, and D. Huang. 2014. Light affects the chloroplast ultrastructure and post-storage photosynthetic performance of watermelon (Citrullus lanatus) plug seedlings. PLoS One 9:E111165.
Hassell, R., F. Memmott, and D. Liere. 2008. Grafting methods for watermelon production. HortScience 43:1677-1678.

Heins, R.D., M. Kaczperski, T. Wallace, N. Lange, W. Carlson, and J. Flore. 1995. Low-temperature storage of bedding plant plugs. Acta Hort. 396:285-296.

Justus, I. and C. Kubota. 2010. Effects of low temperature storage on growth and transplant quality of non-grafted and grafted cantaloupe-type muskmelon seedlings. Sci. Hort. 125:47-54.

King, S., A. Davis, X. Zhang, and K. Crosby. 2010. Genetics, breeding and selection of rootstocks for Solanaceae and Cucurbitaceae. Sci. Hort. 127:106-111.

Ko, B.R., S.W. Kwon, M.J. Jaskani, and J.S. Choi. 2006. Fatty acid composition and $\mathrm{fad} 3$ gene expression in roots of watermelon and gourd under low temperature. Acta Hort. (710):377-382.

Kubota, C., N.C. Rajapakse, and R.E. Young. 1996. Low temperature storage of micropropagated plantlets under selected light environment. HortScience 31:449-452.

Kubota, C., S. Seiyama, and T. Kozai. 2002. Manipulation of photoperiod and light intensity in low-temperature storage of eggplant plug seedlings. Sci. Hort. 94:13-20.

Kwack, Y. and C. Chun. 2015. Changes in quality and vigor of cucumber and paprika transplants as affected by storage temperature under dark conditions. Korean J. Hort. Sci. Technol. 33:633-637.

Lee, S.H., G.C. Chung, and E. Steudle. 2005a. Gating of aquaporins by low temperature in roots of chilling-sensitive cucumber and chilling-tolerant figleaf gourd. J. Expt. Bot. 413:985-995.

Lee, S.H., G.C. Chung, and E. Steudle. 2005 b. Low temperature and mechanical stresses differently gate aquaporins of root cortical cells of chilling-sensitive cucumber and -resistant figleaf gourd. Plant Cell Environ. 28:1191-1202.
Lee, J.-M., C. Kubota, S.J. Tsao, Z. Bie, P. Hoyos Echevarria, L. Morra, and M. Oda. 2010. Current status of vegetable grafting: Diffusion, grafting techniques, automation. Sci. Hort. 127:93-105.

Ntatsi, G., D. Savvas, H.P. Kläring, and D. Schwarz. 2014. Growth, yield, and metabolic responses of temperature-stressed tomato to grafting onto rootstocks differing in cold tolerance. J. Amer. Soc. Hort. Sci. 139:230-243.

Park, J.S. and K. Fujiwara. 2009. Quality preservation of tomato seedlings affected by different wavelengths of LED-low light during storage. Eur. J. Hort. Sci. 74:2123.

Park, J.S. and K. Fujiwara. 2015. Storage of grafted-tomato seedling under lowlight conditions with light-emitting diodes and an electroluminescent sheet. Hort. Environ. Biotechnol. 56:472-477.

Petropoulos, S.A., E.M. Khah, and H.C. Passam. 2012. Evaluation of rootstocks for watermelon grafting with reference to plant development, yield and fruit quality. Intl. J. Plant Prod. 6:481-491.

Pullano, G. 2016. Project sharpens interest in benefits of vegetable grafting. 3 Nov. 2016. <http://vegetablegrowersnews. $\mathrm{com} /$ news/project-sharpens-interest-inbenefits-of-vegetable-grafting $>$.

Schwarz, D., G. Öztekin, Y. Tüzel, B. Brückner, and A. Krumbein. 2013. Rootstock can enhance tomato growth and quality characteristics at low potassium supply. Sci. Hort. 149:70-79.

Spalholz, H. 2013. Development of short term storage techniques for grafted vegetable seedlings. MS Thesis, Univ. Arizona, Tucson, AZ.

Wang, R.X., Z. Guo, and Y.S. Ao. 2009. Physiological adaptation and recovery of eggplant plug seedlings to low temperature and low-intensity light during storage. J. Hort. Sci. Biotechnol. $84: 209-215$ 